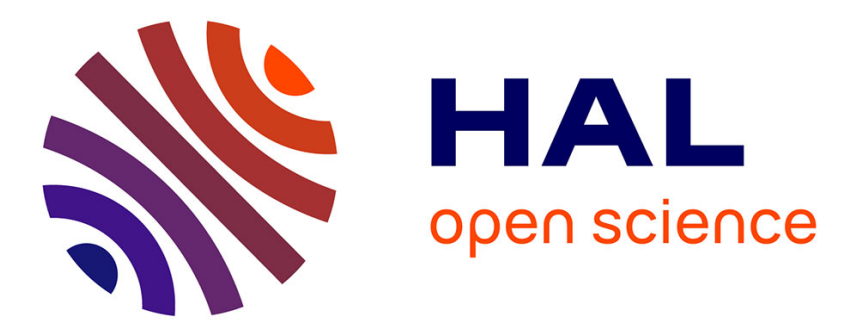

\title{
In-mouth salt release measurement during food chewing using sensors
}

Marion Emorine, Patrick Mielle, Jacques Maratray, Thierry Thomas-Danguin, Christian Salles

\section{- To cite this version:}

Marion Emorine, Patrick Mielle, Jacques Maratray, Thierry Thomas-Danguin, Christian Salles. Inmouth salt release measurement during food chewing using sensors. 14. International Symposium on Olfaction and Electronic Nose, May 2011, New-York, United States. 2 p., 10.1063/1.3626322 . hal-01137040

\section{HAL Id: hal-01137040 \\ https://hal.science/hal-01137040}

Submitted on 30 Mar 2015

HAL is a multi-disciplinary open access archive for the deposit and dissemination of scientific research documents, whether they are published or not. The documents may come from teaching and research institutions in France or abroad, or from public or private research centers.
L'archive ouverte pluridisciplinaire HAL, est destinée au dépôt et à la diffusion de documents scientifiques de niveau recherche, publiés ou non, émanant des établissements d'enseignement et de recherche français ou étrangers, des laboratoires publics ou privés. 


\title{
In-mouth salt release measurement during food chewing using sensors
}

\author{
Marion Emorine ${ }^{\mathrm{a}}$, Patrick Mielle ${ }^{\mathrm{a}}$, Jacques Maratray ${ }^{\mathrm{a}}$, \\ Thierry Thomas-Danguin ${ }^{\mathrm{a}}$ and Christian Salles ${ }^{\mathrm{a}}$ \\ ${ }^{a}$ Centre des Sciences du Goût et de l'Alimentation, UMR- 6265 CNRS, UMR-1324 INRA, \\ Université de Bourgogne, AgroSup, Dijon, France
}

\begin{abstract}
In most countries, health authorities recommend a $20 \%$ reduction of the salt content in manufactured food products. Understanding the release of taste compounds from food is essential to better known the mechanism of flavour perception, in order to develop low salt products that are acceptable to the consumers. In this aim, two sensors have been designed to allow the in-mouth monitoring of conductivity from 0.34 to $340 \mathrm{mM} \mathrm{NaCl}$ and temperature during mastication of hot snacks as conductivity is highly dependant on the temperature.
\end{abstract}

Keywords: $\mathrm{NaCl}$ monitoring, food chewing, salt, sensory.

PACS: 06.60.Ei, 07.05.Kf, 07.07.Df

\section{INTRODUCTION}

Salt $(\mathrm{NaCl})$ consumption is recognized as an important factor in the rise of hypertension in industrialized countries. Therefore, health authorities recommend a $20 \%$ reduction of the salt content (salt generally is present about 0.5 to $2 \mathrm{~g}$ per $100 \mathrm{~g}$ of food) in food products. Understanding the release of taste compounds from food is essential to better known the mechanism of flavour perception, in order to develop low salt products that are acceptable to the consumers. Some sensors have been designed up to now [1], [2], but no measure of release of sodium has been measured and correlated to the measurement of temperature for hot food taste.

In this aim, two sensors have been designed to allow the in-mouth monitoring of conductivity and temperature during mastication. The size and the in-mouth location of this sensors have been optimized to reduce disturbance by either the mastication or the salivation of the assessors. The tiniest sensors are rice-grain sized.

\section{RESULTS AND DISCUSSION}

The novel device uses a four-electrode Wenner array, gold-plated design, which enables to get rid of particles and clogging effects on the measurement. Different electrodes design have been evaluated, that are driven by a clamped bipolar voltage to avoid polarization effects, with a safe and non-prickling value. As most of the time, meals of snacks are served either hot or chilled, but rarely at ambient temperature, and condugtidity yis AIP Conf. Proc. 1362, 102-103 (2011); doi: 10.1063/1.3626322 C 2011 American Institute of Physics 978-0-7354-0920-0/ $\$ 30.00$ 
implemented together with the sensor, allowing software compensation. It doesn't embed any electronic part to remain compliant with experimentation rules on humans and to allow sterilization.

Different electrode design have been evaluated for the in-mouth sensor, and the most widely accepted by panellists is the tiniest one $(5 \times 2 \mathrm{~mm}$, Fig. 1$)$, and the two outboard wires are so thin $(21 \mu \mathrm{m})$ that they can easily pass thru the interdental gap, keeping the mouth its tightness. One set of sensors were made for each of the panellists, and were independently calibrated for temp, ranging from 20 to $50{ }^{\circ} \mathrm{C}$ and for conductivity using the panellist's training saline solutions, ranging from 0.34 to $340 \mathrm{mM} \mathrm{NaCl}$ (Fig. 2). The day-to-day standard deviation is quite fair (less than $5 \%$ ).

This device, together with the software temperature compensation provides in realtime the weighted salt concentration in saliva during chewing. Comparison can be made with the human perception of saltiness during mastication, and the device is also compatible with our Artificial Mouth, with will allow comparison between in-vivo and in-vitro data.
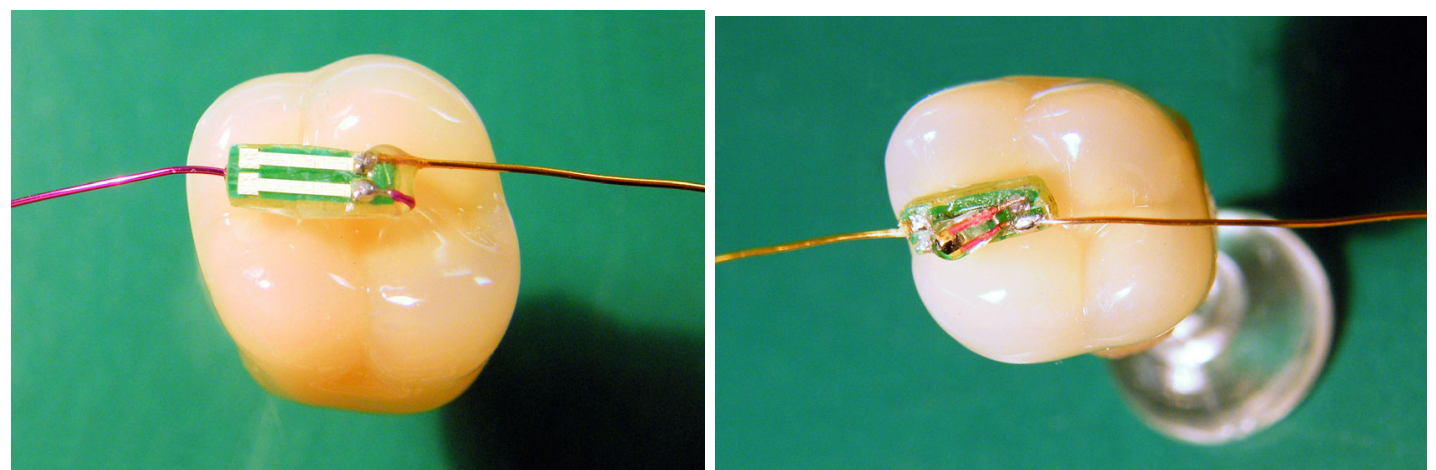

FIGURE 1. Left part: the in-mouth conductivity sensor;

Right part: the in-mouth temperature sensor. Size is given by the molar.
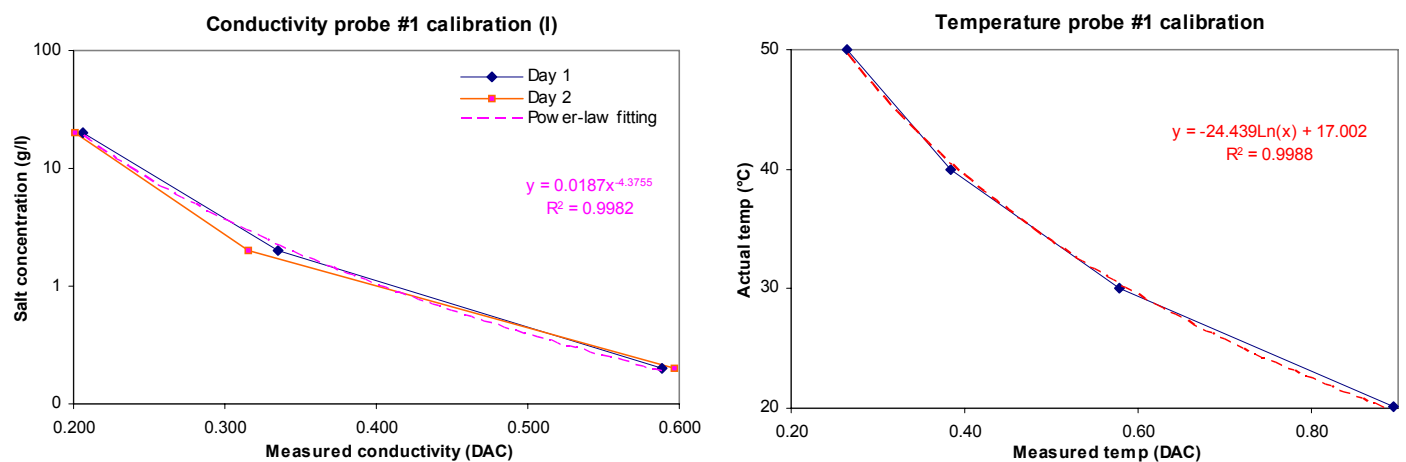

FIGURE 2. Left part: calibration curve of the conductivity sensor; right part: calibration curve of the temperature sensor.

\section{REFERENCES}

1. E. Neyraud, J. Prinz, E. Dransfield, " $\mathrm{NaCl}$ and sugar release, salivation and taste during mastication of salted chewing gum”, Physiology \& Behavior 79, pp. 731-737, 2003.

2. J.M. Davidson, R.S.T. Linforth, and A.J. Taylor, "In-Mouth Measurement of $\mathrm{pH}$ and Conductivity during Eating”, J. Agric. Food Chem. 46, pp. 5210-5214, 1998. 